\title{
Tumoración ulcerada en un párpado
}

\author{
MJ. Massoquoia , C. Hernando Rovirolab ${ }^{b}$ R. Savall López-Reynals`, V. Cusí Sánchez ${ }^{\text {d }}$ \\ aParamédica. Hospital Saint John of God. Sierra Leona. \\ ${ }^{b}$ Médico de Familia. Hospital Saint Jhon of God. Sierra Leona. \\ 'Dermatóloga. Hospital Viladecans. Barcelona. España. \\ ‘Patóloga. Servicio de Anatomía Patológica. Hospital Sant Joan de Déu. Barcelona. España.
}

\begin{abstract}
Resumen
Se presenta un caso de un niño con una tumoración ulcerada en el párpado inferior izquierdo con adenopatías regionales bilaterales que precisó biopsia cutánea para su diagnóstico.

El resultado era consistente con primoinfección herpética. La lesión evolucionó favorablemente con tratamiento antibiótico y antiinflamatorio por vía oral, hasta su curación. La posibilidad de primoinfección herpética pseudotumoral debe plantearse como diagnóstico diferencial de lesiones neoplásicas.
\end{abstract}

Palabas clave: Herpes virus. Pseudotumor. Párpado.

Ulcerated eyelid tumoral lesion

Abstract

We report a child with an ulcerated pseudotumoral lesion in the left eyelid accompanied by bilateral neck adenopathies due to a primary herpes virus infection. Differential diagnosis with neoplasms and a proper therapy of the infection resulted in a complete cure of the lesion.

Key words: Herpes virus. Pseudotumoral lesion. Eyelid.

\section{Caso clínico}

Niño de ocho años natural y residente en Sierra Leona que consultó al hospital Saint John of God en Sierra Leona por una tumoración en el párpado inferior del ojo izquierdo con un tiempo de evolución de alrededor de un mes. El padre refería un antecedente de contacto con hojas de la papaya.

Durante la exploración presentaba una tumoración dura que ocupaba los dos tercios externos del párpado inferior izquierdo, con ulceraciones en la superficie cutánea y en la mucosa de dicho

Roser Savall López-Reynals, rsavall@gmail.com

Los autores declaran no presentar conflictos de intereses en relación con la preparación y publicación de este artículo. 
Figura 1. Tumoración en el párpado.

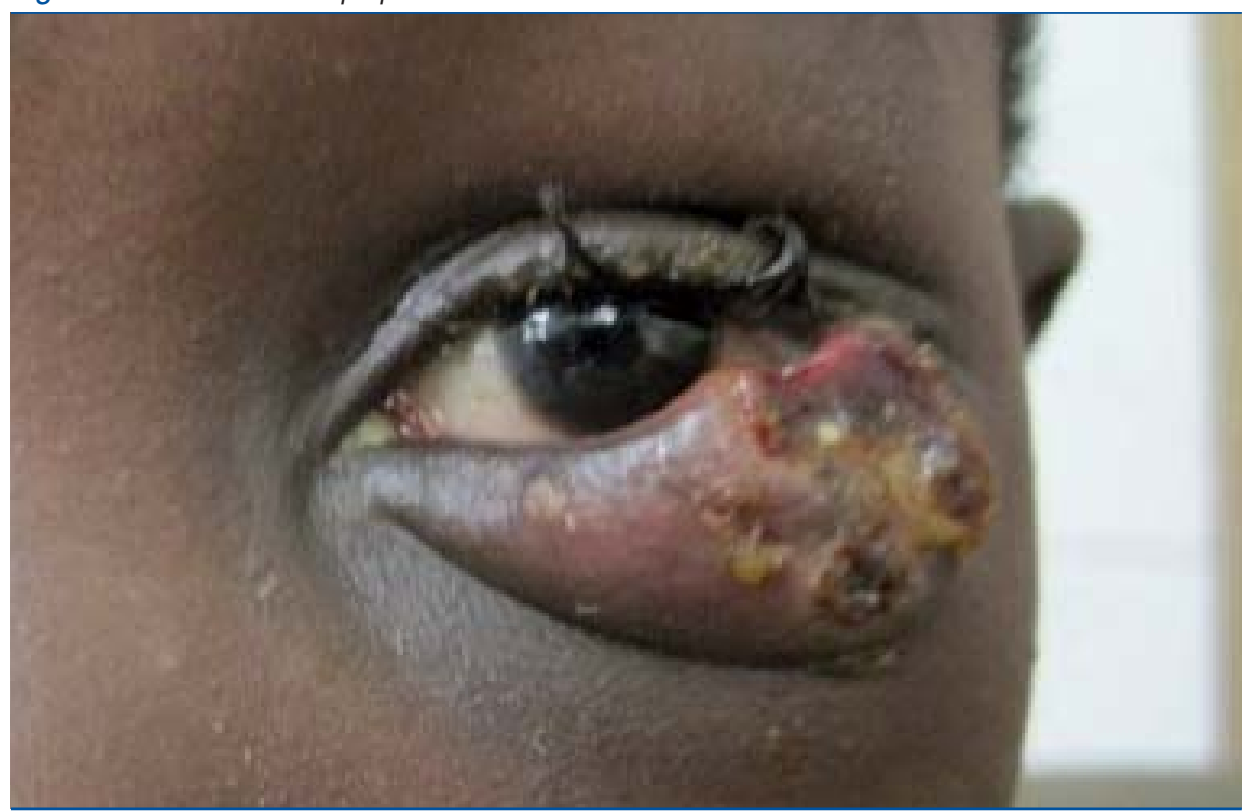

párpado (figura 1). También existían adenopatías en ambos lados del cuello. El resto de la exploración no presentaba datos relevantes.

La imposibilidad de realizar cultivos microbiológicos en el terreno obligó a administrar una cobertura antibiótica sistémica y local como primera opción terapéutica por si se trataba de un proceso infeccioso. Se administró amoxicilina/ácido clavulánico por vía oral, y tobramicina y aciclovir tópicos. Pero el síntoma que más destacaba era la consistencia pétrea de la tumoración, junto con las adenopatías regionales que sugerían un proceso neoformativo. Final- mente, el contacto con la papaya hizo considerar la posibilidad de que se tratara de una dermatitis de contacto al látex que exudan estos frutos cuando están verdes. Se realizó una biopsia cutánea, que se envió a un hospital de referencia.

El estudio anatomopatológico mostró un exudado con fibrina y polinucleares en la zona superficial de la úlcera y un tejido de granulación en las regiones profundas, donde se identificaron histiocitos con inclusiones intranucleares de tipo herpético y células multinucleadas gigantes con núcleos que conenían cuerpos de inclusión intranucleares (figura 2). El músculo esquelético de la 
Figura 2. Células multinucleadas en la biopsia de la tumoración.

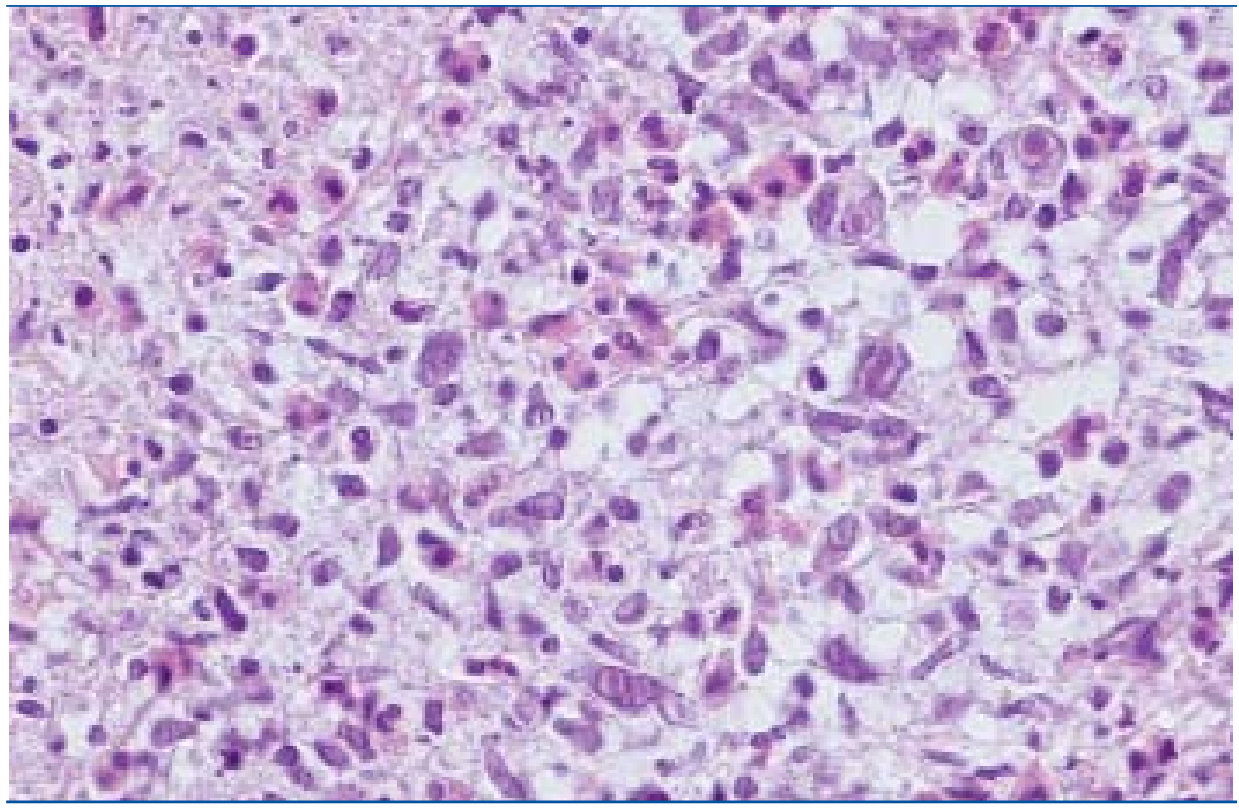

Figura 3. Curación a los dos meses.

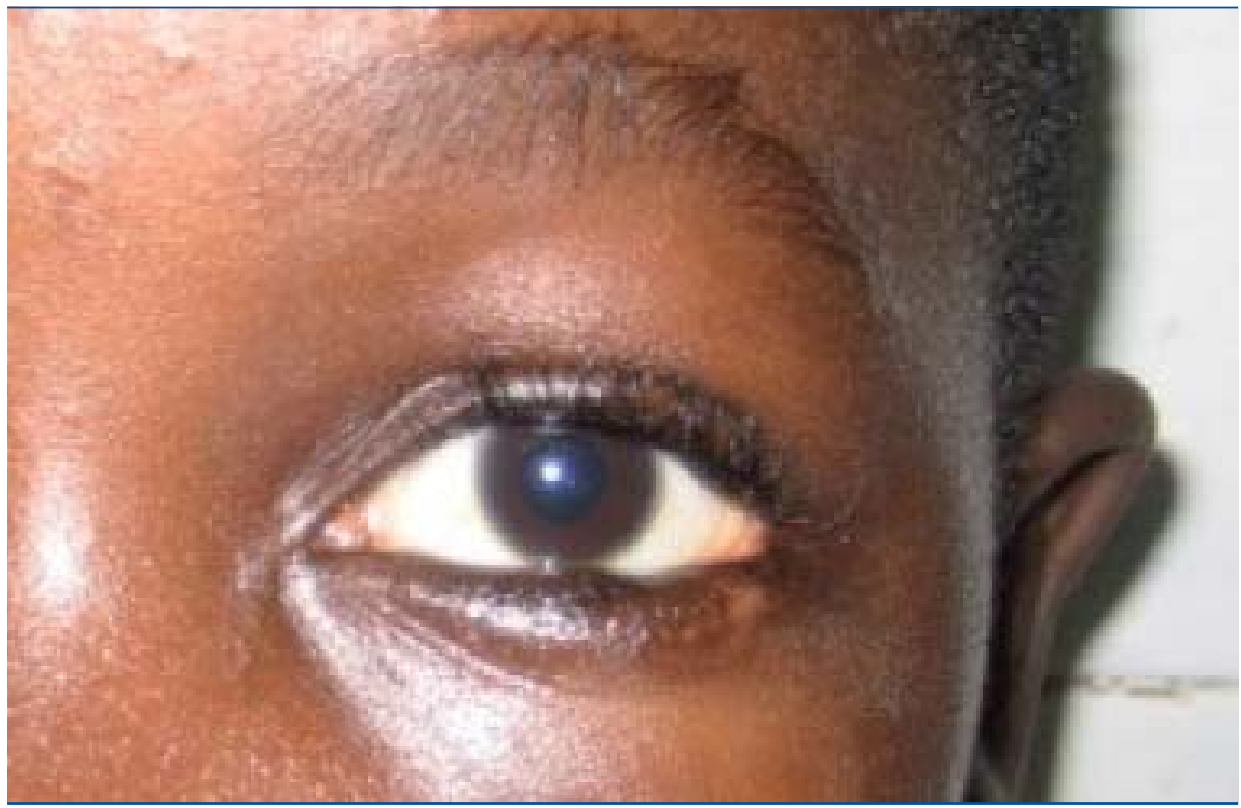


zona más profunda de la biopsia mostraba una reacción inflamatoria focal no específica. La tinción de PAS fue negativa. El diagnóstico fue: lesión ulcerada de características compatibles con infección por herpes virus, acompañada de sobreinfección probablemente bacteriana.

A las tres semanas, la tumoración del párpado inferior empezó a disminuir de tamaño, así como la induración, al tiempo que cicatrizaron las ulceraciones. Al mes y medio, la reparación era total (figura 3).

\section{Comentario}

La primoinfección herpética es el primer contacto del virus herpes simple (VHS) con un individuo. El VHS pertenece a la familia de los Herpesviridae, de la que actualmente se conocen ocho especies que pueden causar patología en el hombre. Todos los virus herpes son encapsulados, contienen doble cadena de $A D N^{2}$, y tienen la capacidad de persistir en estado latente e inducir inclusiones intranucleares en las células infectadas.

La localización cutánea o mucosa de la primera infección suele ser de características más violentas que las infecciones posteriores o recurrencias ${ }^{3}$. Así, por ejemplo, la gingivoestomatitis herpética es una primoinfeción por el virus del herpes que se presenta con un cuadro de úlceras en las encías y en la mucosa bucal y faríngea extremadamente dolorosas y que se acompañan de fiebre alta, adenopatías y mal estado general que puede remedar el debut de una leucemia. En la piel, el primer episodio de herpes simple siempre es más florido que los episodios posteriores. Se manifiesta con la aparición de vesículas arracimadas de contenido seroso que se rompen con mucha facilidad dejando ulceraciones superficiales. Producen escozor o malestar local.

La primoinfección por el virus del herpes simple es más frecuente en la infancia en países en desarrollo y en estratos socioeconómicos más deprimidos donde la masificación y el estrecho contacto entre las personas ofrece mayor oportunidad al contagio. Si a la fragilidad del sistema inmunitario infantil se suma la inmunodepresión relativa de los niños en el África subsahariana, como resultado de una alimentación y una higiene deficitarias, pueden presentarse casos de infección por el virus del herpes simple muy aparatosas, como esta forma pseudotumoral en el párpado, que pueden confundirse con rabdomiosarcomas, tumores palpebrales o tumores intraoculares 4 . 


\section{Bibliografía}

1. El mundo de las plantas. Propiedades de la papaya [consultado el 15/09/2010]. Disponible en www.botanical-online.com

2. Cook GC, Zumla Al. Manson's Tropical Diseases. 21.th ed. Edinburgh, UK: Elsevier Science Limited; 2002. p. 848-9.
3. Rey CJ. Infección herpética. Barcelona: Ediciones Doyma, S.A.; 1991

4. Martínez E. Diagnóstico diferencial del ojo rojo. X Curso de Educación continuada en Medicina Interna. Hospital Clínico Universitario de Chile. Medwave [consultado el 15/09/2010]. Disponible en http://www.medwave.cl/aten cion/adultos/hospclinicouchile2005/10/1.act 